\title{
A new insight into apheresis platelet donation by sickle cell trait carriers: evidences of safety and quality
}

Suzanna Araujo Tavares Barbosa ${ }^{1}$, Denise Menezes Brunetta ${ }^{1}$, Sérgio Luiz Arruda Parente Filho ${ }^{2 *}$, Guilherme de Alencar Salazar Primo ${ }^{2}$, Franklin José Candido Santos ${ }^{1}$, Luciana Maria de Barros Carlos ${ }^{1}$, Naliele Cristina Maia de Castro ${ }^{1}$, Juan Daniel Zuñiga Pro and Elizabeth De Francesco Daher ${ }^{2}$

${ }^{1}$ Hematology and Hemotherapy Center of Ceara, Brazil

${ }^{2}$ Department of Internal Medicine, School of Medicine, Federal University of Ceará. Fortaleza, Ceará, Brazil

\section{Introduction}

In countries with a high prevalence of the sickle cell trait (SCT), which is often determined by neonatal screening programs, a significant proportion of blood donors may be SCT carriers [1]. In Brazil, for example, where SCT prevalence ranges from $1.1 \%$ to $9.8 \%$ in the overall population [2], the trait is found in up to $2.48 \%$ of blood donors [3-7]. Because individuals with SCT are usually asymptomatic, many of them are unaware of their condition at the time of donation [1]. Considering the potential risks associated with SCT blood donation for both donor and recipient, particularly those with sickle cell disease [8], routine HbS screening in first-time blood donations is generally recommended [9].

After the implementation of universal leukoreduction in several countries, the management and use of SCT blood products became a challenge for blood banks. The trait represents the most common cause of filter failure [10], and the units that manage to pass through the filter may have prolonged filtration time and high residual white blood cell (WBC) counts, despite the use of high performance filters [11]. These results appear to be a consequence of mechanical differences in SCT red blood cells (RBCs), which are inherently stiffer and more viscous than those from healthy donors [12].

As a result, some countries have issued specific recommendations regarding the processing and use of SCT RBCs products. In Brazil, RBCs products with the SCT cannot undergo leukoreduction and their use is prohibited in some clinical scenarios, such as patients with hemoglobinopathies, severe acidosis or hypothermia [13]. The American Association of Blood Banks (AABB) [14] and the European Committee on Blood Transfusion (ECBT) [15] have similar recommendations. Therefore, SCT donors should preferentially donate non-RBC products [16]. In this context, plateletpheresis may be a promising alternative to maximize SCT donors. However, there is a blank regarding safety of such donations. For instance, ECBT prohibits SCT carriers to donate RBC products by apheresis, but there is no mention to apheresis platelet donation [15], which is often allowed or prohibited based on Blood Banks' experience only.

Current standards have defined cut-off values of the main parameters used in the assessment of in vitro apheresis platelets quality. Actual platelet yield, $\mathrm{pH}$ and residual WBC count are specified in virtually all major standards for apheresis platelets quality, but with some slight differences in their threshold values. The Brazilian Ministry of Health's (BMH) technical regulation for hemotherapy procedures and the AABB Standards for Blood Banks and Transfusion Services agree in recommendations for two of these parameters: a minimum platelet yield of $3 \times 10^{11}$ platelets in $90 \%$ of sampled units and a residual WBC count below $5 \times 10^{6}$ per unit $[13,14]$. On the other hand, the European Committee on Blood Transfusion is less demanding, requiring a platelet yield of at least $2 \times 10^{11}$ per unit and a residual leukocyte count below $3 \times 10^{8}$ per unit [15]. The AABB indicates that at least $90 \%$ of apheresis platelets should have a $\mathrm{pH} \geq 6.2$ at the end of the storage time [14], while the European and the Brazilian regulations specify a $\mathrm{pH}$ greater than 6.4 at the end of shelf-life, with additional recommendation for volume and, in the Brazilian requirements, a negative culture result $[13,15]$.

This study sought to assess the frequency of apheresis platelet donation by SCT carriers, the safety of the procedure to this population of donors and the in vitro quality of their apheresis platelet concentrates.

\section{Methods}

This is a retrospective study which included all apheresis platelet donations by SCT carriers between January 2013 and December 2016 at Hematology and Hemotherapy Center of Ceara, Brazil. Apheresis platelet units were obtained using Trima Accel $^{\circledR}$ Automated Blood Collection System (Terumo BCT, Denver, USA). Hemoglobin status was screened by electrophoresis and the result was confirmed by high performance liquid chromatography. All data were obtained using the blood bank software.

Information on in vitro quality parameters of plateletpheresis was only available for the years of 2015 and 2016. AABB, ECBT and the $\mathrm{BMH}$ recommendations were used as standards for apheresis platelets quality. Parameters of SCT donors were compared to those of a control group composed of non-SCT carriers matched for sex who donated in the same period. For each SCT donor, two non-SCT donors were included in the control group. There was one exception: only one female non-SCT donor was included to pair with one of the female SCT donors in that period, since no other female match was available, because of the transfusion-related acute lung injury (TRALI) prevention protocol.

The data were analyzed using SPSS 20.0 for Windows (SPSS Inc. Chicago, IL, USA) and expressed as mean \pm standard deviation (SD). The Kolgomorov-Smirnov test was used to sort out variables which

${ }^{\star}$ Correspondence to: Sérgio Luiz Arruda Parente Filho, Rua Gotardo Gomes Gurgel, 60, Edson Queiroz, Fortaleza, Ceará-60834-434, Brazil, E-mail: sergioparente_@hotmail.com

Received: May 02, 2019; Accepted: June 06, 2019; Published: June 10, 2019 
follow a gaussian curve from those which do not. In order to compare variable means between groups, Student's $t$ or Mann-Whitney tests were performed accordingly.

\section{Results}

A total of 2,434 platelet donors were included, accounting for 5930 donations. Hemoglobin electrophoresis was performed in 1921 donors (78.93\%). Of those, 27 (1.4\%) had the SCT, 1885 were homozygous for $\mathrm{HbA}(98.1 \%)$ and 9 were heterozygous for $\mathrm{HbC}(0.46 \%)$. The only variables that followed a normal distribution were concentrates' platelet yield and donors' pre-donation platelet count.

The overall mean number of donations per individual was $2.44 \pm$ 4.38 , with median of 1 and maximum of 83 donations, as shown in Table 1. A total of 1,431 donors (62.9\%) donated only once in the period of the study.

The SCT group was responsible for 104 donations (1.75\%), with a mean, median and maximum number of donations per individual of $3.85 \pm 6.86,1$ and 35 respectively. There was no statistically significant difference between the SCT and non-SCT donors's mean number of donations $(3.85 \pm 6.86$ vs. $2.44 \pm 4.38, p=0.096)$. One-time donors accounted for $48.1 \%$ (13 individuals) of SCT participants. None of the SCT donors presented any side-effect or complication that may have arisen due to apheresis donation, whilst $24 \mathrm{HbAA}$ donors presented 25 episodes of adverse reactions to the donation, mainly hypocalcemic symptoms.
Platelet quality parameters were available for 13 SCT donors, eleven of which were males $(84.61 \%)$. Mean age in this group was $33.69 \pm$ 12.47 years. Twenty-five donors were included in the control group, with 22 males $(88 \%)$ and mean age of $37.84 \pm 11.50$ years. There was no statistically significant difference in age $(37.84 \pm 11.50$ vs. $33.69 \pm$ 12.47 years, $\mathrm{p}=0.312)$ or pre-donation platelet count $(254.84 \pm 56.17$ vs. $254.31 \pm 66.11$ thousand platelets $/ \mathrm{mm}^{3}, \mathrm{p}=0.979$ ) between the two groups, as showed in Table 2 .

Table 3 displays the cut-off values recommended by the ECBT, AABB and the $\mathrm{BMH}$ followed by a comparison between in vitro parameters for quality assessment of the apheresis platelet units collected from the SCT group and the control group.

All apheresis platelet units from both groups met the requirements recommended by all three criteria. Mean values of platelet yield $(5.03 \pm$ 1.52 vs. $4.84 \pm 1.3810^{11}$ platelets/unit, $\left.\mathrm{p}=0.715\right)$, residual WBC $(0.07 \pm$ 0.02 vs. $0.08 \pm 0.0410^{6} \mathrm{WBC} /$ unit, $\left.\mathrm{p}=0.975\right), \mathrm{pH}(7.63 \pm 0.26$ vs. 7.69 $\pm 0.25, \mathrm{p}=0.362)$ and volume per unit $(339.76 \pm 98.71$ vs. $340.05 \pm$ $98.91 \mathrm{~mL} / \mathrm{unit}, \mathrm{p}=0.963$ ) did not show statistically relevant difference between groups and all platelet units had negative cultures in the first 24 hours following collection. A positive swirling test was observed in all platelet units.

\section{Discussion}

Although SCT causes no lifespan shortening or clinical repercussions in the majority of cases, some specific situations, such

Table 1. Comparison of number of donations and episodes of adverse reaction in all participants and in the SCT group

\begin{tabular}{|c|c|c|c|c|c|c|}
\hline & \multicolumn{5}{|c|}{ Number of donations } & \multirow{2}{*}{ Adverse Reactions } \\
\hline & Mean & Median & Minimum & Maximum & Total & \\
\hline $\begin{array}{l}\text { All donors } \\
(\mathrm{n}=\mathbf{2 4 3 4})\end{array}$ & $2.44 \pm 4.38$ & 1 & 1 & 83 & 5,930 & 25 \\
\hline $\begin{array}{l}\text { SCT donors } \\
(\mathbf{n}=\mathbf{2 7})\end{array}$ & $3.85 \pm 6.86^{\#}$ & 2 & 1 & 35 & 104 & 0 \\
\hline $\begin{array}{l}\text { Non-SCT donors } \\
(\mathrm{n}=\mathbf{2 4 0 7})\end{array}$ & $2.42 \pm 4.34^{\#}$ & 1 & 1 & 83 & 5826 & 25 \\
\hline p-value & $0.096^{\#}$ & --- & --- & --- & --- & --- \\
\hline
\end{tabular}

${ }^{\#}$ Mann-Whitney test. P-values $\leq 0.05$ were considered statistically significant.

Table 2. Comparison of donor's features between the SCT and the control group

\begin{tabular}{|c|c|c|c|}
\hline & \multicolumn{2}{|l|}{ Mean values } & \multirow[b]{2}{*}{ p-value } \\
\hline & $\begin{array}{l}\text { Control group } \\
(\mathrm{n}=26)\end{array}$ & $\begin{array}{l}\text { SCT group } \\
(\mathrm{n}=13)\end{array}$ & \\
\hline Pre-donation platelet count $\left(10^{3} / \mathrm{mm}^{3}\right)$ & $254.84 \pm 56.17$ & $254.31 \pm 66.11$ & $0.979^{*}$ \\
\hline $\begin{array}{l}\text { Age } \\
\text { (years) }\end{array}$ & $37.84 \pm 11.50$ & $33.69 \pm 12.47$ & $0.312^{*}$ \\
\hline
\end{tabular}

*Student's $t$ test. P-values $\leq 0.05$ were considered statistically significant.

Table 3. Cut-off values of quality parameters recommended by ECBT, AABB and BMH and comparison between mean values of quality control parameters of SCT and control groups

\begin{tabular}{|c|c|c|c|c|c|c|}
\hline & \multirow{2}{*}{$\begin{array}{c}\text { ECBT's } \\
\text { recommendation }\end{array}$} & \multirow{2}{*}{$\begin{array}{c}\text { AABB's } \\
\text { recommendation }\end{array}$} & \multirow{2}{*}{$\begin{array}{c}\text { BMH's } \\
\text { recommendation }\end{array}$} & \multicolumn{2}{|c|}{ Mean values } & \multirow[b]{2}{*}{ p-value } \\
\hline & & & & Control group $(n=26)$ & $\begin{array}{l}\text { SCT group } \\
(n=13)\end{array}$ & \\
\hline $\begin{array}{l}\text { Platelet yield } \\
\left(10^{11} / \text { unit }\right)\end{array}$ & $>2$ & $>3$ & $>3$ & $5.03 \pm 1.52$ & $4.84 \pm 1.38$ & $0.715^{*}$ \\
\hline $\begin{array}{l}\text { Residual WBC count } \\
\text { (10\%/unit) }\end{array}$ & $<300$ & $<5$ & $<5$ & $0.07 \pm 0.02$ & $0.08 \pm 0.04$ & $0.975^{\#}$ \\
\hline $\mathrm{pH}$ & $>6.4$ & $>6.2$ & $>6.4$ & $7.63 \pm 0.26$ & $7.69 \pm 0.25$ & $0.362^{\#}$ \\
\hline $\begin{array}{l}\text { Volume } \\
\left(\mathrm{mL} / 6 \times 10^{10} \text { platelets }\right)^{\mathrm{a}} \\
(\mathrm{mL} / \mathrm{unit})^{\mathrm{b}}\end{array}$ & $>40^{\mathrm{a}}$ & --- & $>200^{\mathrm{b}}$ & $339.76 \pm 98.71^{\mathrm{b}}$ & $340.05 \pm 98.91^{b}$ & $0.963^{\#}$ \\
\hline Negative culture & --- & --- & Negative & --- & --- & --- \\
\hline Swirling & Positive & Positive & Positive & --- & --- & --- \\
\hline
\end{tabular}

ECBT, European Committee on Blood Transfusion. AABB, American Association of Blood Banks. BMH, Brazilian Ministry of Health. SCT, Sickle cell trait. WBC, White blood cell count. *Student's t test. \# Mann-Whitney test. P-values $\leq 0.05$ were considered statistically significant. 
as severe dehydration and exercise, may trigger kidney lesions, rhabdomyolysis or even death in SCT carriers [17]. This is, to our knowledge, the first study to objectively assess the safety of platelet apheresis donation by SCT carriers and the in vitro quality parameters of their platelet concentrates.

Considering all types of apheresis procedures, plateletpheresis is the second cause of donors' adverse reactions, behind only plasmapheresis [18]. Possible adverse reactions include blood access injuries, vasovagal symptoms and alkalosis caused by citrate overload [18]. In the present study, no SCT donor presented any adverse reaction to the apheresis procedure. Furthermore, the mean number of donations from SCT individuals was similar to that from the overall population and there was no statistically significant difference from the non-SCT group. Such findings suggest that there is no adverse reaction specific to SCT donors that could force this group to discontinue apheresis donation over time.

Whilst buffy-coat platelet concentrates must undergo leukoreduction after collection in order to avoid adverse reactions, plateletpheresis returns leukocytes back to the donor's circulation during collection [19]. It is considered a very efficient procedure, at least in non-SCT blood. Nevertheless, whether the apheresis technique is as efficient in depleting leukocytes from SCT blood was an unanswered question. The present study showed a similar residual WBC count in both SCT and control groups, as showed in Table 3.

Previous studies have analyzed the in vitro quality of apheresis platelets, particularly the $\mathrm{pH}$ of the concentrates [20,21]. In one of these studies, a strong correlation of platelet $\mathrm{pH}$ values was found within donors. Furthermore, an association was found between certain donor characteristics, namely age and sex, and a low platelet yield [21]. Both findings suggest a role of donor characteristics in the quality of their platelet products. In none of these studies, however, hemoglobin status has been specified as one of these characteristics.

The quality of a blood component is also influenced by storage lesion, which is an umbrella term that refers to the various mechanisms of deterioration of blood components during storage. Platelets are especially sensitive to bacterial contamination and storage lesion caused by exposure to foreign surfaces, shear stress during centrifugation, acidic $\mathrm{pH}$, trauma, amongst other factors [22]. As a result, platelets units present a short shelf-life of 5 days in average if stored at $22^{\circ} \mathrm{C}$ $\left(71.6^{\circ} \mathrm{F}\right)$, with the possibility of being extended to 7 days if stored at $18^{\circ} \mathrm{C}\left(64.4^{\circ} \mathrm{F}\right)$ or if additive solutions are used [23].

Measurement of $\mathrm{pH}$ is an important tool for evaluating storage lesion. Values of $\mathrm{pH}$ below 6.0 cause irreversible damage to platelets, which become improper for use. The fall in $\mathrm{pH}$ is ascribed to the production of $\mathrm{CO}_{2}$ due to platelet anaerobic glucose metabolism [24]. The platelet yield is a parameter primarily linked to the purpose of the platelet transfusion. In other words, if a platelet unit does not gather enough platelets, its quality is obviously poor, once the clinical endresult will be compromised. However, a recent study has demonstrated that if the platelet count is too high (above $5 \times 10^{11}$ platelets per unit) in platelet units that underwent Intercept pathogen inactivation, an increase in storage lesion rates was observed, especially in apheresis platelets [25]. In the present work, there was no statistically significant difference of $\mathrm{pH}$ and platelet yield between the SCT and the control group.

Although it is not mandatory, the swirling test is another useful way of assessing the quality of platelets, more precisely, their morphological integrity. It consists of a qualitative test, in which light is cast through the platelet concentrate. It is said to be positive when the light is scattered by the unit content, which is an indirect sign that the platelets are morphologically preserved [15]. In our sample, all concentrates presented positive swirling, regardless of belonging to the SCT group or not.

\section{Conclusion}

Apheresis platelet concentrates from SCT donors have similar quality parameters to those from non-SCT donors. No increase in the rates of adverse reactions was observed in the SCT group. Therefore, SCT individuals seem to be as good source of apheresis platelets as the general population and blood banks which struggle with scarcity of platelet donations may greatly benefit from routinely allowing SCT individuals to donate by plateletpheresis, especially where there is a high SCT prevalence. Further studies with a greater number of SCT participants and laboratory evaluation of extracorporeal circulation effects may help to better elucidate this issue.

\section{Acknowledgement}

Financial support from Coordenação de Aperfeiçoamento de Pessoal de Nível Superior (CAPES) and Conselho Nacional de Desenvolvimento Científico e Tecnológico (CNPq).

\section{References}

1. Ohene-Frimpong K, Oduro J, Tetteh H, Nkrumah F (2008) Screening newborns for sickle cell disease in Ghana. Paediatrics 121(suppl 2): S120-S1201.

2. Lervolino LG, Baldin PEA, Picado SM, Calil KB, Viel AA, et al. (2011) Prevalence of sickle cell disease and sickle cell trait in national neonatal screening studies. Rev Bras Hematol Hemoter 33: 49-54.

3. Naoum PC (2000) Prevalência e controle da hemoglobina S. Rev Bras Hematol Hemoter 22 (supl 2): 142-148.

4. Mello SMA, Arantes SCF, Botelho Filho A, Rocha AFS (2000) Prevalência de hemoglobinopatias em doadores de sangue do Hemocentro Regional de UberlândiaMG. Bol Soc Bras Hematol Hemoter 20: 130.

5. Orlando GM, Naoum PC, Siqueira FAM, Bonini-Domingos CR (2000) Diagnóstico laboratorial de hemoglobinopatias em populações diferenciadas. Rev Bras Hematol Hemoter 22: 111-121.

6. Acedo MJ, Costa VA, Polimeno NC, Bertuzzo CS (2002) Programa comunitário de hemoglobinopatias: abordagem populacional a partir de doadores de sangue de Bragança Paulista, São Paulo, Brasil. Cad Saude Publica 18: 1799-1802.

7. Lisot CLA, Silla LMR (2004) Triagem de hemoglobinopatias em doadores de sangue de Caxias do Sul, RS, Brasil: prevalência em área de colonização italiana. Cad Saude Publica 20: 1595-601.

8. Thurston GB, Henderson NM, Jeng M (2004) Effects of erythrocytapheresis transfusion on the viscoelasticity of sickle cell blood. Clin Hemorheol Microcirc 30: 83-97.

9. Piccin A (2010) Do we need to test blood donors for sickle cell anaemia? Blood Transfus 8: 137-138. [Crossref]

10. Schuetz AN, Hillyer KL, Roback JD, Hillyer CD (2004) Leukoreduction filtration of blood with sickle cell trait. Transfusion medicine reviews 18: 168-176.

11. Amar KO, Bourdonné O, Bruneau S, Sellami F, Richard P (2014) Assessment of leucoreduction of sickle cell trait blood: quality of the filtered product. Blood Transfusion 12(Suppl 1): s193.

12. Zheng Y, Cachia MA, Ge J, Xu Z, Wang C, et al. (2015) Mechanical differences of sickle cell trait (SCT) and normal red blood cells. Lab Chip 15: 3138-3146. [Crossref]

13. Saúde Md (2016) Redefine o regulamento técnico de procedimentos hemoterápicos, in Portaria $n^{\circ} 158$, de 04 de fevereiro de 2016. Diário Oficial da União, DF.

14. AABB (2014) Standards for Blood Banks and Transfusion Services. (29th Edn) Bethesda, MD: AABB.

15. European Committee (Partial Agreement) on Blood Transfusion (2017) Guide to the preparation, use and quality assurance of blood components (19th Edn).

16. Krailadsiri P, Gilcher R, Seghatchian J (2001) Leukoreduction of sickle cell trait blood an unresolved issue. Transfusion and Apheresis Science 24: 223-225. 
17. Thompson AA (2013) Sickle cell trait testing and athletic participation: a solution in search of a problem? Hematology Am Soc Hematol Educ Program pp. 632-637.

18. Heuft HG, Fischer E, Weingand T (2017) Donor Safety in Haemapheresis: Development of an Internet-Based Registry for Comprehensive Assessment of Adverse Events from Healthy Donors. Transfus Med Hemother 44: 188-200.

19. van der Meer PF (2013) Platelet concentrates, from whole blood or collected by apheresis? Transfus Apher Sci 48: 129-131. [Crossref]

20. Germain (2017) Quality control of apheresis platelets: a multicentre study to evaluate factors that can influence $\mathrm{pH}$ measurement." Vox sanguinis 112.4: 318-325.

21. Tudisco, Cynthia (2005) The value of $\mathrm{pH}$ as a quality control indicator for apheresis platelets. Transfusion 45.5: 773-778.
22. Mittal K, Kaur R (2015) Platelet storage lesion: An update. Asian J Transfus Sci 9: 1-3. [Crossref]

23. Chandra T, Gupta A, Kumar A (2014) Extended shelf life of random donor platelets stored for 7 days in platelet additive solution at different temperatures. Biomed $J 37$ : 211-217.

24. Murphy S, Gardner FH (1975) Platelet storage at 22 degrees C: role of gas transport across plastic containers in maintenance of viability. Blood 46: 209-218.

25. Feys HB (2017) High platelet content can increase storage lesion rates following Intercept pathogen inactivation primarily in platelet concentrates prepared by apheresis. Vox Sang 112: 751-757.

Copyright: (C2019 Barbosa SAT. This is an open-access article distributed under the terms of the Creative Commons Attribution License, which permits unrestricted use, distribution, and reproduction in any medium, provided the original author and source are credited. 